\title{
Karst environments and disturbance: evaluation of the effects of human activity on grassland and forest naturalness in dolines
}

\author{
Dianne Joy Aguilon ${ }^{1,2,3}$ (1) András Vojtkó ${ }^{4} \cdot$ Csaba Tölgyesi $^{1}$ (1) - László Erdös ${ }^{5}$ (1) Péter János Kiss ${ }^{1,2}$. \\ Gábor Lőrinczi ${ }^{1}$ (I) $\cdot$ Orsolya Juhász ${ }^{1,6} \cdot$ Kata Frei $^{1} \cdot$ Zoltán Bátori $^{1}$ (B)
}

Received: 11 February 2020 / Accepted: 7 May 2020 / Published online: 18 May 2020

(C) The Author(s) 2020

\begin{abstract}
Karst depressions (dolines) have the potential to act as safe havens for a high diversity of valuable species. We showed that local anthropogenic disturbances play a significant role in determining the naturalness of dolines. We compared the number of specialist species, competitor species, generalist species and species of disturbed habitats between natural and disturbed dolines in two Hungarian karst areas, where different types of anthropogenic disturbances have been shaping the vegetation for centuries. We found that these disturbances have the potential to negatively influence the naturalness of dolines, reducing the number of valuable species, thus affecting the conservation value of dolines. To maintain the naturalness of vegetation in these doline habitats, the populations of ruderal competitors should be eliminated, and sustainable forest management should be adapted. However, there are still open questions about the effects of different disturbances on the naturalness in dolines that need to be answered to determine which conservation strategies will be particularly suitable for valuable species in a warming climate.
\end{abstract}

Keywords Climate change $\cdot$ Logging $\cdot$ Refugia $\cdot$ Threatened species $\cdot$ Vegetation

\section{Introduction}

Karst regions constitute about $20 \%$ of the earth's total dry land surface (White et al. 1995). They are composed of mainly carbonate rocks that have undergone dissolution over time, resulting in unique landscape elements, including caves, disappearing streams and local depressions (dolines or

Dianne Joy Aguilon

ddaguilon@up.edu.ph

1 Department of Ecology, University of Szeged, Közép fasor 52, H-6726 Szeged, Hungary

2 Doctoral School of Environmental Sciences, University of Szeged, Rerrich Béla tér 1, H-6720 Szeged, Hungary

3 Department of Forest Biological Sciences, College of Forestry and Natural Resources, University of the Philippines Los Baños, 4031 Laguna, Philippines

4 Department of Botany, Eszterházy Károly University of Applied Sciences, Eszterházy tér 1, H-3300 Eger, Hungary

5 Institute of Ecology and Botany, Centre for Ecological Research, Alkotmány út 2-4, H-2163 Vácrátót, Hungary

6 Doctoral School in Biology, Faculty of Science and Informatics, University of Szeged, Közép fasor 52, H-6726 Szeged, Hungary sinkholes), to name just a few (Ford and Williams 2007). Nowadays, karst ecosystems are highly vulnerable and are undergoing degradation due to various anthropogenic activities such as deforestation, quarrying, mineral extraction, dumping of illegal waste to dolines and tourism in caves (Parise and Pascali 2003). These human-induced disturbances comprise environmental pressures leading to polluted aquifers, destroyed caves and dolines, declining biodiversity and denuded landscapes (Van Beynen et al. 2012). Since dolines are the most common and diagnostic of all karst landforms (Sauro 2003; Ford and Williams 2007; Li et al. 2007), the evaluation of the effects of different disturbances on their biota is crucial for improving current and developing future conservation strategies, especially in the context of global climate change.

Topographic variables (e.g., geometry, size and slope aspect) and related environmental conditions (e.g., air temperature, air humidity and soil moisture) are known to play a major role in determining biodiversity patterns in dolines (Whiteman et al. 2004; Öztürk and Savran 2020). Their bottoms and north-facing slopes maintain cooler, moister and more humid environments than the surrounding plateaus (Bátori et al. 2019). As a result, doline habitats may serve as refuges (for decades) or refugia (for millennia) for vulnerable taxa, such as endemic, montane and relict species (Vilisics et al. 2011; Bátori et al. 2012; Kemencei et al. 2014; Raschmanová et al. 
2015). Many of these species can be under threat because of global warming (Bátori et al. 2019). In addition, dolines are considered to form a significant link between surface and underground ecosystems and play a key role in the geological and ecological processes of karst surfaces (Gams 2000). Therefore, dolines warrant special attention from a conservation point of view (Redžić et al. 2011; Bátori et al. 2014).

The degradation of dolines is among the most pressing issues in karst environments worldwide (Parise and Pascali 2003; De Waele 2009; North et al. 2009; Kovačič and Ravbar 2013). Dolines have been cultivated extensively, providing sites for various traditional activities such as arable farming, gardening, pasturing and water extraction (Breg 2007). Serious degradation due to urbanization and disposal of a variety of waste materials have been widely documented in the dolines of Central and Southern Europe (Kovačič and Ravbar 2013; Breg Valjavec et al. 2018a, b). Disturbances may compromise the capacity of dolines to act as safe havens for species during future climate oscillations (Kiss et al. 2020) and, as a result, may also reduce the naturalness of their habitats.

It has been recognized that plants can be used as bioindicators and are able to indicate the naturalness of their habitat (Ellenberg 1950). The approach of naturalness indicator values is similar to that of the original Ellenberg-type indicator values and has been used successfully to study disturbance (Erdős et al. 2017a, b). Some species indicate disturbed sites, while others prefer less-disturbed or natural habitats. For instance, the presence of a large number of endemic, habitat specialist and endangered species within a habitat usually indicates higher naturalness and thus higher conservation value (Angermeier and Karr 1994; Trombulak et al. 2004).

Although recent studies have shed light on the role of climate, geometry, slope aspect and vegetation cover on the distribution of different taxa in dolines (Bátori et al. 2017), data on the effects of human activity on the naturalness of doline vegetation are sparse. To fill this gap, the present study seeks to compare the naturalness of grassland (invaded by Clamagrostis epigejos vs. non-invaded) and forested habitats (young forests vs. old forests) in the dolines of two Hungarian karst areas using the naturalness indicator values of plants. Specifically, the following question was addressed: How different types of human activities influence the naturalness of doline habitats? Results will improve our understanding about how human activity affects the biota of these potential refugia, which is necessary to develop appropriate management strategies.

\section{Material and methods}

\section{Study sites}

Two study sites were selected in Hungary (1: Bükk Mts, 700$800 \mathrm{~m}$ a.s.l.; mean average temperature: $6.3^{\circ} \mathrm{C}$; mean average precipitation: $800 \mathrm{~mm}$, and 2: Mecsek Mts, $300-500 \mathrm{~m}$ a.s.l.; mean average temperature: $9.5{ }^{\circ} \mathrm{C}$; mean average precipitation: $750 \mathrm{~mm}$ ) for vegetation sampling (Dövényi 2010) (Fig. 1). The study site in the Bükk Mts is covered with various grassland types. Semi-dry grasslands, dry grasslands (southfacing slopes) and mesic and/or wet grasslands (bottoms and north-facing slopes) can be found within the dolines. Previous cultivation and lime burning have led to the invasion of Calamagrostis epigejos in many dolines (Bátori et al. 2020). Larger dolines in the Mecsek Mts are covered with oakhornbeam forests (upper slopes; Carpinus betulus, Fagus sylvatica, Quercus petraea and Q. cerris are the dominant tree species), beech forests (lower slopes; Fagus sylvatica is the dominant tree species) and ravine forests (bottoms; Acer campestre, A. platanoides, A. pseudoplatanus, Carpinus betulus, Fagus sylvatica and Fraxinus excelsior are the dominant tree species). Due to forestry practices, current forest stands mainly include $40-50,60-80$ or $90-120$-year-old trees. Forest thinning is frequent in the younger forests $(<50$-yearold).

\section{Sampling design}

We sampled six (three 'natural' and three 'disturbed') larger (diameter: 60-85 m, depth: 7-15 $\mathrm{m}$ in the Bükk Mts; diameter: 55-105 m, depth: $10-16 \mathrm{~m}$ in the Mecsek Mts) solution dolines in both study sites. Natural dolines in the Bükk Mts are covered by semi-dry, dry, and wet grasslands, while disturbed dolines can be characterized with a high cover of Calamagrostis epigejos. Natural dolines in the Mecsek Mts are covered with 90 to 120-year-old trees, while disturbed dolines, which are characterized by a markedly higher intensity of forest management, are covered mostly with 40 - to 50 -year-old trees. We established a transect with north to south orientation across each doline, traversing their deepest point. Transects consisted of $1 \times 1 \mathrm{~m}$ plots spaced at $2 \mathrm{~m}$ intervals. We recorded the presence/absence of all herbs, shrubs and tree seedlings and saplings in each plot. Fieldwork was carried out from July to August in the Bükk Mts and from June to August in the Mecsek Mts, at the peak of the growing season. Nomenclature follows 'The Plant List' (www.theplantlist.org).

\section{Statistical analyses}

Percentage frequency of each species was determined both for the natural and disturbed dolines. Diagnostic species analysis was performed to identify species that prefer one specific habitat type (natural or disturbed dolines). The phi coefficient $(\Phi)$ was applied as an indicator of the fidelity of a species to a certain habitat (Chytrý et al. 2002). The phi coefficient varies between -1 and +1 , and higher phi values indicate higher diagnostic values. In this study, species with phi values higher than 0.2 were considered. Significant diagnostic species were 
Fig. 1 Location of the study sites (Bükk and Mecsek Mts) in Hungary. Thick lines indicate the borders of the geographic macroregions of Hungary

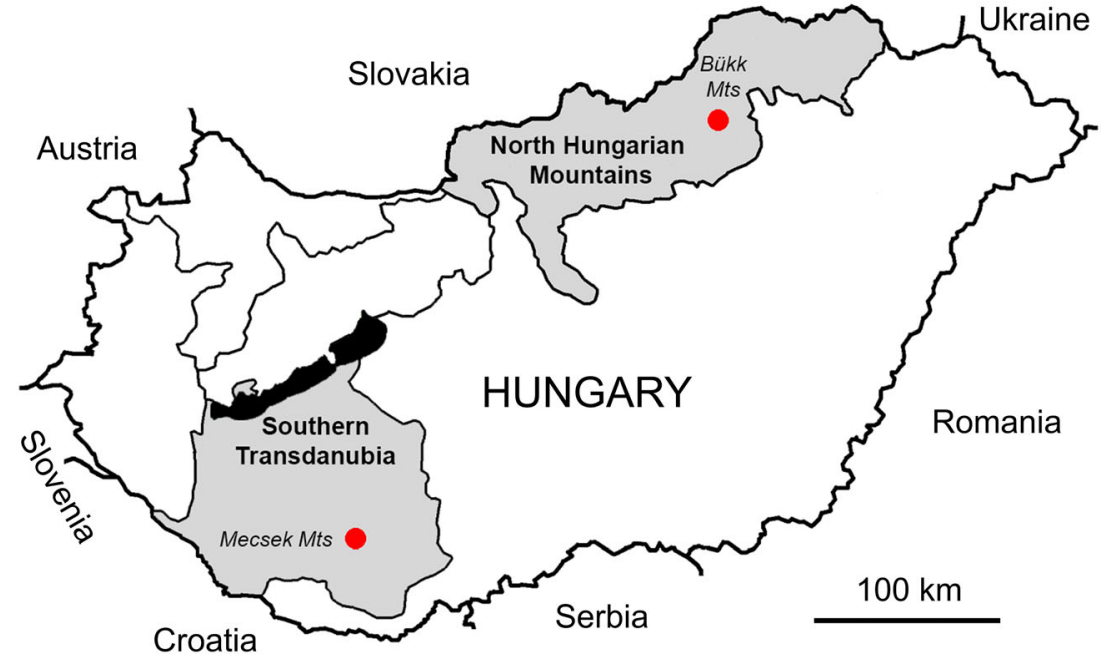

identified by Fisher's exact test $(p<0.01)$. Analyses were performed with JUICE 7.0.45 (Tichý 2002).

The differences in the vegetation composition of the two habitat types (natural vs. disturbed dolines) were assessed by non-metric multidimensional scaling (NMDS, Jaccard index) ordinations and one-way analysis of similarities (ANOSIM, Jaccard index) using 9999 permutations. The analyses were performed in R (R Core Team, 2018) using the 'metaMDS' and 'anosim' functions of the vegan package (Oksanen et al. 2019).

Prior to the analysis, each species was classified according to its social behavior type. We used the "Social Behavior Types" (SBT) of Borhidi (1995), which are defined for the Pannonian biogeographical region, to characterize the naturalness of dolines. Four main groups of species were analyzed: 1 - specialist species, 2 - competitor species, 3 - generalist species and 4 - species of disturbed habitats (disturbance tolerant species, natural pioneers, weeds and ruderal competitors). Generalized linear mixed models (GLMMs) with a Poisson distribution were used to compare the social behavior types of the habitats. In each model, the habitat type (natural vs. disturbed) was used as a fixed factor, the number of species with different social behavior types as a response variable, while the sampling location (i.e. transect) as a random factor. GLMMs were prepared in R using the 'glmer' function of the lme4 package (Bates et al. 2013; R Core Team 2018).

\section{Results}

The most frequent species of the natural dolines in the Bükk Mts were Arrhenatherum elatius (66\%), Iris sibirica (57\%), Stachys officinalis (54\%), Festuca rupicola (52\%) and Brachypodium pinnatum (51\%), while in the disturbed dolines Calamagrostis epigejos (72\%), Arrhenatherum elatius (71\%), Fragaria viridis (62\%), Galium mollugo (56\%), Festuca rupicola (44\%), Cruciata glabra (44\%) and
Veronica chamaedrys (44\%) were the most frequent (Table 1). In the Mecsek Mts, Lamium galeobdolon (88\%), Hedera helix (64\%), Acer pseudoplatanus (59\%), Mercurialis

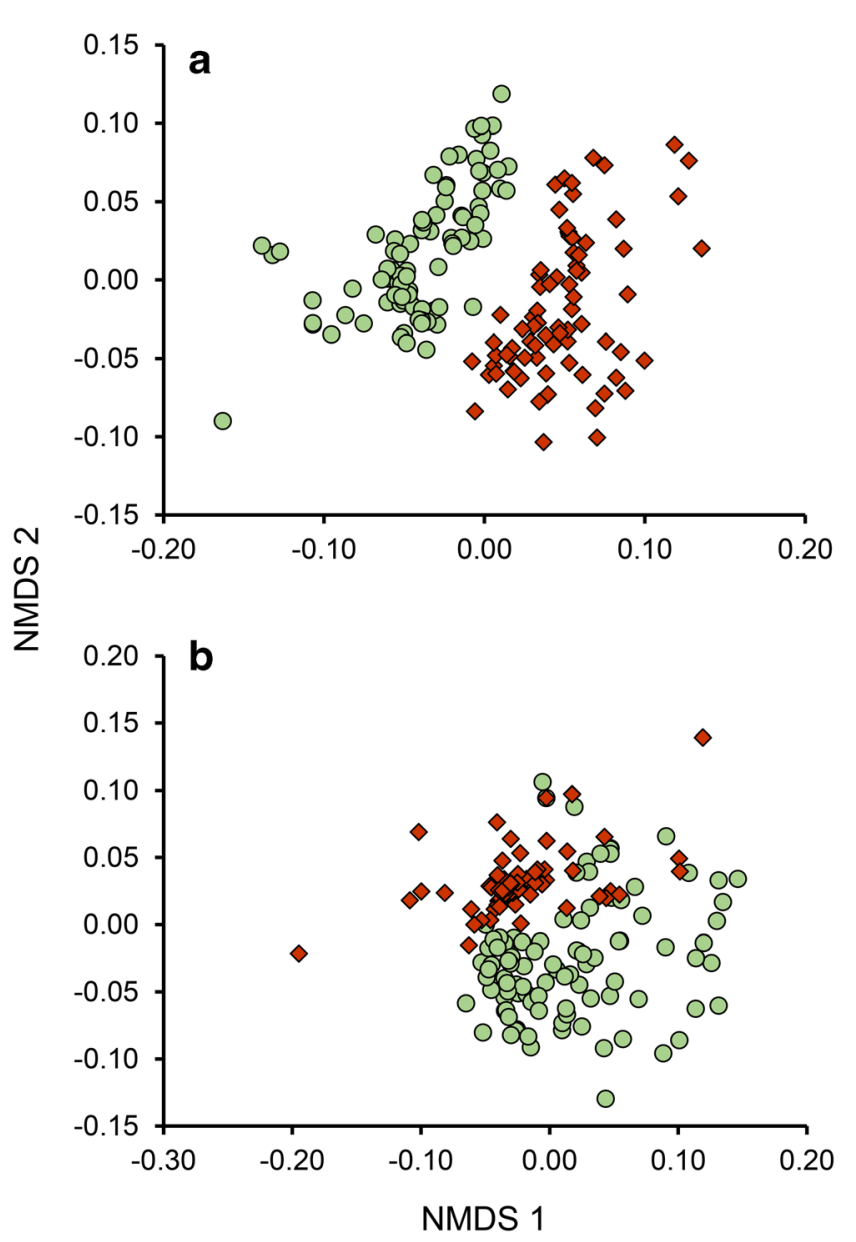

Fig. 2 Non-metric multidimensional scaling (NMDS) ordinations of the plots in natural and disturbed dolines in (a) the Bükk and (b) the Mecsek Mts, Hungary. Different colors indicate different habitat types (green: natural, red: disturbed) 
Table 1 List of diagnostic species for natural $(\mathrm{N})$ and disturbed (D) dolines in the Bükk Mts (Hungary). Capital letters in parentheses (S, C, $\mathrm{G}$ and $\mathrm{D}$ ) indicate the four main groups of species, such as S: specialist species, C: competitor species, G: generalist species and D: species of disturbed habitats (disturbance tolerant species, natural pioneers, weeds and ruderal competitors), bold numbers indicate fidelity values $(\Phi \times 100)$, while numbers in parentheses indicate the percentage frequency of species

\begin{tabular}{|c|c|c|}
\hline & $\mathrm{N}$ & $\mathrm{D}$ \\
\hline Iris sibirica $(\mathrm{S})$ & $61.8(57)$ & $(0)$ \\
\hline Stachys officinalis (G) & $59.3(54)$ & $(0)$ \\
\hline Brachypodium pinnatum $(\mathrm{C})$ & $56.8(50)$ & $(0)$ \\
\hline Filipendula vulgaris $(\mathrm{G})$ & $49.5(41)$ & $(0)$ \\
\hline Geranium sanguineum $(\mathrm{C})$ & $43.7(34)$ & $(0)$ \\
\hline Molinia caerulea $(\mathrm{C})$ & $43.7(34)$ & $(0)$ \\
\hline Seseli libanotis $(\mathrm{G})$ & $42.0(32)$ & $(0)$ \\
\hline Calamagrostis arundinacea $(\mathrm{G})$ & $41.1(31)$ & $(0)$ \\
\hline Euphorbia lucida $(\mathrm{G})$ & $39.4(29)$ & (0) \\
\hline Aconitum variegatum $(\mathrm{S})$ & $38.6(28)$ & (0) \\
\hline Phleum phleoides $(\mathrm{G})$ & $38.6(33)$ & (3) \\
\hline Potentilla erecta (D) & $35.1(41)$ & (10) \\
\hline Filipendula ulmaria $(\mathrm{G})$ & $34.1(22)$ & (0) \\
\hline Centaurea phrygia subsp. indurata $(\mathrm{G})$ & $33.1(21)$ & (0) \\
\hline Gentiana pneumonanthe (S) & $32.2(20)$ & (0) \\
\hline Thalictrum lucidum $(\mathrm{G})$ & $30.3(18)$ & (0) \\
\hline Helictotrichon alpinum $(\mathrm{G})$ & $30.1(23)$ & (3) \\
\hline Peucedanum palustre $(\mathrm{G})$ & $29.3(17)$ & (0) \\
\hline Cirsium pannonicum $(\mathrm{G})$ & $28.2(16)$ & (0) \\
\hline Waldsteinia geoides $(\mathrm{G})$ & $28.2(16)$ & (0) \\
\hline Verbascum lychnitis $(\mathrm{G})$ & $28.0(21)$ & (3) \\
\hline Iris variegata $(\mathrm{G})$ & $27.2(15)$ & (0) \\
\hline Luzula luzuloides (C) & $25.6(21)$ & (4) \\
\hline Digitalis grandiflora $(\mathrm{G})$ & $25.0(13)$ & (0) \\
\hline Veronica austriaca subsp. dentata $(\mathrm{G})$ & $25.0(13)$ & $(0)$ \\
\hline Calamagrostis epigejos (D) & (9) & $64.0(72)$ \\
\hline Veronica chamaedrys (D) & (12) & $35.6(44)$ \\
\hline Euphorbia cyparissias (D) & (0) & $34.5(23)$ \\
\hline Carex hirta (D) & $(0)$ & $33.4(22)$ \\
\hline Colchicum autumnale $(\mathrm{G})$ & (6) & $32.6(33)$ \\
\hline Cirsium eriophorum (D) & $(0)$ & $32.2(20)$ \\
\hline Thymus pulegioides subsp. pannonicus (G) & (2) & $29.0(22)$ \\
\hline Carex pallescens $(\mathrm{D})$ & (15) & $28.2(41)$ \\
\hline Bromus erectus $(\mathrm{C})$ & $(0)$ & $27.5(15)$ \\
\hline Ranunculus polyanthemos $(\mathrm{G})$ & (7) & $27.4(29)$ \\
\hline Sanguisorba minor $(\mathrm{G})$ & (2) & $26.5(19)$ \\
\hline Alchemilla monticola $(\mathrm{G})$ & $(0)$ & $26.2(14)$ \\
\hline Rhamnus cathartica $(\mathrm{G})$ & (1) & $26.2(16)$ \\
\hline Trifolium montanum $(\mathrm{G})$ & (9) & $25.8(29)$ \\
\hline Cardamine pratensis $(\mathrm{G})$ & $(0)$ & $24.9(13)$ \\
\hline Euphorbia salicifolia (D) & (0) & $24.9(13)$ \\
\hline Trifolium alpestre $(\mathrm{G})$ & (13) & $24.8(34)$ \\
\hline Primula veris $(\mathrm{G})$ & (1) & $23.5(14)$ \\
\hline
\end{tabular}

perennis (54\%), Galium odoratum (43\%) and Viola reichenbachiana $(43 \%)$ were the most frequent species in the natural dolines, while Hedera helix (74\%), Acer pseudoplatanus (69\%), Carpinus betulus (63\%), Lamium galeobdolon (54\%) and Viola reichenbachiana (31\%) were the most frequent species in the disturbed dolines (Table 2). In total, we could identify 43 diagnostic species in the dolines of the Bükk Mts (Table 1). Twenty-five species were
Table 2 List of diagnostic species for natural $(\mathrm{N})$ and disturbed (D) dolines in the Mecsek Mts (Hungary). Capital letters in parentheses (S, $\mathrm{C}, \mathrm{G}$ and $\mathrm{D}$ ) indicate the four main groups of species, such as S: specialist species, C: competitor species, G: generalist species and D: species of disturbed habitats (disturbance tolerant species, natural pioneers, weeds and ruderal competitors), bold numbers indicate fidelity values $(\Phi \times 100)$, while numbers in parentheses indicate the percentage frequency of species

\begin{tabular}{lll}
\hline & $\mathrm{N}$ & $\mathrm{D}$ \\
\hline Mercurialis perennis $(\mathrm{C})$ & $\mathbf{5 8 . 3}(54)$ & $(0)$ \\
Galium odoratum $(\mathrm{C})$ & $\mathbf{4 9 . 8}(43)$ & $(0)$ \\
Tilia tomentosa $(\mathrm{C})$ & $\mathbf{4 4 . 0}(38)$ & $(1)$ \\
Lamium galeobdolon $(\mathrm{G})$ & $\mathbf{3 8 . 2}(88)$ & $(54)$ \\
Rubus hirtus agg. $(\mathrm{D})$ & $\mathbf{3 7 . 6}(30)$ & $(1)$ \\
Melica uniflora $(\mathrm{C})$ & $\mathbf{3 4 . 6}(29)$ & $(3)$ \\
Fraxinus excelsior $(\mathrm{C})$ & $\mathbf{3 2 . 3}(21)$ & $(0)$ \\
Fagus sylvatica $(\mathrm{C})$ & $\mathbf{3 1 . 4}(30)$ & $(5)$ \\
Hepatica nobilis $(\mathrm{S})$ & $\mathbf{2 9 . 6}(18)$ & $(0)$ \\
Circaea lutetiana $(\mathrm{G})$ & $\mathbf{2 6 . 8}(15)$ & $(0)$ \\
Carex pilosa $(\mathrm{C})$ & $\mathbf{2 5 . 6}(37)$ & $(14)$ \\
Carpinus betulus $(\mathrm{C})$ & $(16)$ & $\mathbf{4 7 . 0}(63)$ \\
\hline
\end{tabular}

diagnostic for natural dolines (e.g., Iris sibirica, Euphorbia lucida and Peucedanum palustre) and 18 species for disturbed dolines (e.g. Calamagrostis epigejos, Carex hirta and Cirsium eriophorum). In the Mecsek Mts, we found 12 diagnostic species for natural dolines (e.g., Circaea lutetiana, Mercurialis perennis and Tilia tomentosa) and only one diagnostic species for disturbed dolines (Carpinus betulus) (Table 2). According to the NMDS analysis, there was a defined gradient between the plots of disturbed and natural dolines in the Bükk Mts (stress value: 0.33), while a slight overlap of the plots was observed in the Mecsek Mts (stress value: 0.35 ) (Fig. 2). Plots belonging to the two habitats were significantly different in their species composition in both areas according to the similarity analysis (Bükk Mts: ANOSIM $\mathrm{R}=0.49, p<0.001$; Mecsek Mts: ANOSIM $\mathrm{R}=$ $0.30, p<0.001$ ).

Significant differences $(p<0.05)$ were observed in all SBT groups except for the generalist species $(p=0.097)$ in the Bükk Mts (Fig. 3). Specifically, specialist and competitor species had a significantly higher $(p<0.001)$ prevalence in natural than in disturbed dolines, while the number of species of disturbed habitats was higher in disturbed dolines $(p=0.001)$. In addition, species of disturbed habitats comprised $41 \%$ of all species in the disturbed dolines (total number of species: 120) and 22\% in the natural dolines (total number of species: 127). However, in the Mecsek Mts, all SBT groups of natural dolines contained significantly higher number of species than those of disturbed dolines $(p<0.05)$ (Fig. 3). Unexpectedly, the number of species of disturbed habitats was significantly higher 
Fig. 3 Number of plant species of the different social behavior types (SBT) in natural and disturbed dolines in (A) the Bükk and (B) the Mecsek Mts, Hungary. Different letters (a and b) above the boxes indicate significant differences, while colors indicate different habitat types (green: natural, red: disturbed). S: specialist species, C: competitor species, G: generalist species and D: species of disturbed habitats (disturbance tolerant species, natural pioneers, weeds and ruderal competitors)
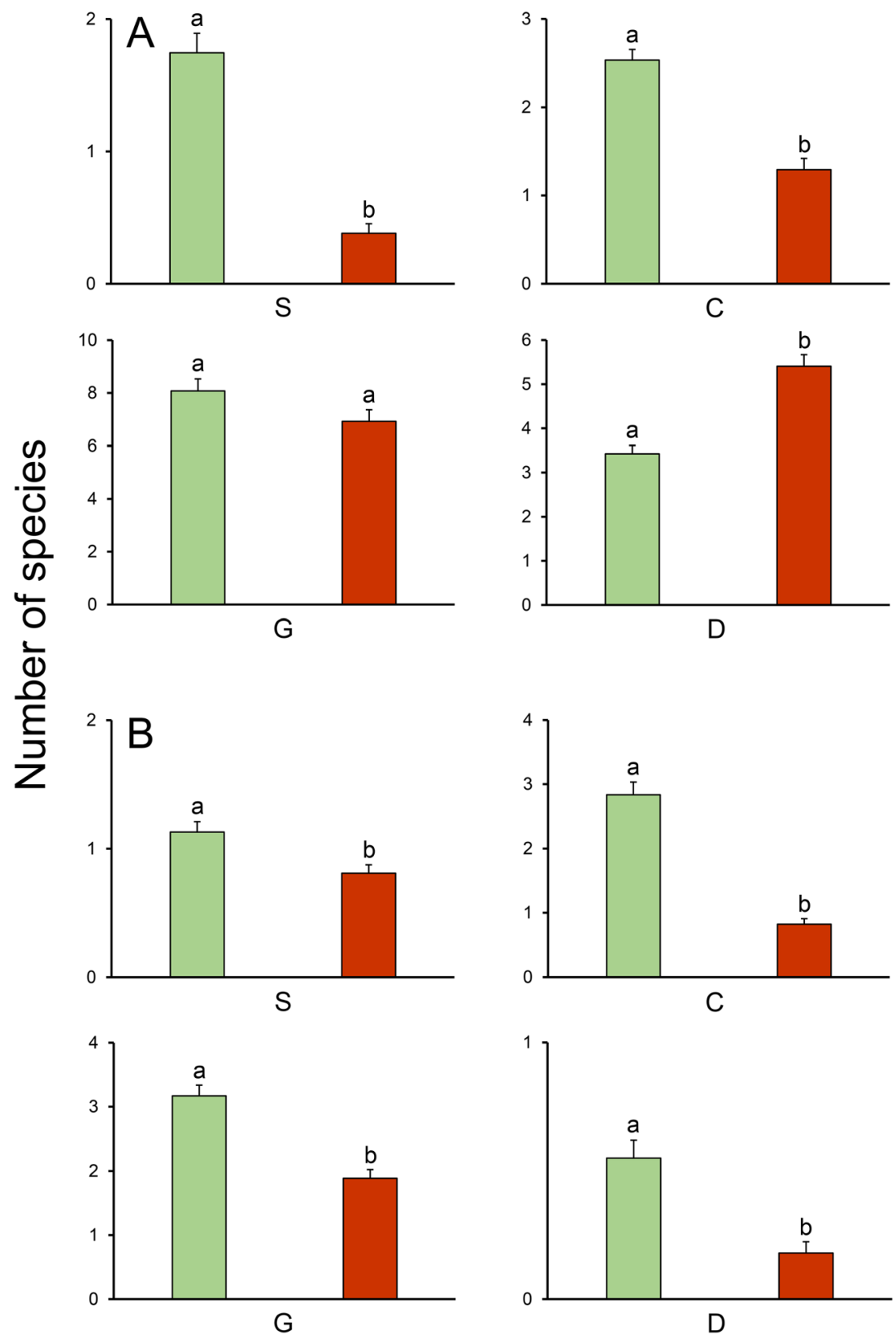

Social behavior types

$(\mathrm{p}<0.05)$ in natural than in disturbed dolines. In addition, species of disturbed habitats comprised $24 \%$ of all species in the disturbed dolines (total number of species: 24) and $17 \%$ in the natural dolines (total number of species: 42 ).

\section{Discussion}

In this study we compared the naturalness of grassland (invaded by Calamagrostis epigejos vs. non-invaded) and forested habitats (young forests vs. old forests) in the dolines of two Hungarian karst areas using the naturalness indicator values of plants. Based on our findings, high numbers of competitors and stress tolerant species (specialist and generalist species) were observed in both noninvaded grassland and old forest habitats (i.e. natural dolines), indicating high naturalness in their vegetation. This is in line with other studies that the high number of certain species (e.g., endemic, habitat specialist and endangered species) within a habitat may indicate higher naturalness (Angermeier and Karr 1994; Trombulak et al. 2004). Our findings further support that dolines with undisturbed habitats have distinct species composition as compared to disturbed dolines (Bátori et al. 2020). 
Human-induced environmental changes have been shown to influence both ecological and evolutionary processes, leading to population extinctions and biodiversity losses (Palumbi 2001; Tilman and Lehman 2001; Stockwell et al. 2003). Karst environments can be prone to such changes. This is also true for dolines, which are known to be highly valuable because of their unique geomorphological feature, microclimate and habitat structure. In addition, they may act as safe havens for cooladapted species under local and global environmental changes (Bátori et al. 2011). Our results suggest that valuable species in dolines are threatened by different human activities, such as the human-mediated invasion of ruderal competitor species (e.g., the invasion of Calamagrostis epigejos) and high levels of forest management (e.g., clear cutting and frequent logging); and one possible way to evaluate the impacts of such human activities on vegetation is the assessment of the naturalness of habitats. We found that various disturbances decreased the number of specialist and competitor species in dolines, thus reducing the naturalness and conservation value of these special habitats. Also, our results suggest that the climatically diverse habitats of karst surfaces are extremely sensitive to anthropogenic disturbances and that their recovery from such disturbances may be slow or may not occur at all (Breg Valjavec et al. 2018b; Bátori et al. 2020).

Interestingly, more species of disturbed habitats (e.g., disturbance tolerant species, natural pioneers and weeds) were observed in dolines covered by old growth forests than in dolines covered by young forests, which might be a result of natural forest dynamic processes. The natural tree-fall gaps or canopy openings created during the falling of old trees led to more light penetration into the lower depths of the canopy and the herb layer, contributing to the appearance of species of disturbed habitats (e.g., some gap species) within the old forest stands (e.g., Galium aparine, Hypericum hirsutum and Urtica dioica in the Mecsek Mts). Similarly, previous studies showed that light conditions strongly affect different plant groups thriving in the understory (Tinya et al. 2009). Furthermore, small-scale disturbances (resulting in single or multiple tree-fall gaps) may also play an important role in driving natural stand dynamics in temperate forests (Pickett and White 1985; Paillet et al. 2010). Plant species that predominantly or exclusively occur in forest gaps are often described as shade-intolerant species, which are typical in non-forested habitats (Goldblum 1997; Anderson and Leopold 2002). If the number of these species is not too high in an old forest, their presence may indicate natural processes and contributes to the maintenance of biodiversity in forested landscapes.

Our findings support that dolines covered by natural vegetation consistently harbor many valuable plant species and indicate high naturalness. However, various types of human disturbances have the potential to affect the degree of naturalness in dolines and alter the capacity of dolines to support valuable species. To increase the naturalness of these doline habitats, the populations of dominant grassland competitors should be suppressed through controlled grazing and/or mowing. The adaptation of sustainable forest management by prohibiting logging or reducing intensity of forestry activities in dolines may contribute to the survival of certain species in a warming climate.

Acknowledgements Open access funding provided by University of Szeged (SZTE) (grant number: 4728). This research was funded by the NKFIH K 124796 grant. The participation of CT was supported by the NKFIH PD 132131 grant. DJA is grateful to the Stipendium Hungaricum Program of the Tempus Public Foundation for her $\mathrm{PhD}$ funding.

Funding NKFIH K 124796, NKFIH PD 132131.

\section{Compliance with ethical standards}

Conflicts of interest The authors declare that they have no conflict of interest.

Open Access This article is licensed under a Creative Commons Attribution 4.0 International License, which permits use, sharing, adaptation, distribution and reproduction in any medium or format, as long as you give appropriate credit to the original author(s) and the source, provide a link to the Creative Commons licence, and indicate if changes were made. The images or other third party material in this article are included in the article's Creative Commons licence, unless indicated otherwise in a credit line to the material. If material is not included in the article's Creative Commons licence and your intended use is not permitted by statutory regulation or exceeds the permitted use, you will need to obtain permission directly from the copyright holder. To view a copy of this licence, visit http://creativecommons.org/licenses/by/4.0/.

\section{References}

Anderson KL, Leopold DJ (2002) The role of canopy gaps in maintaining vascular plant diversity at a forested wetland in New York State. J Torrey Bot Soc 129:238-250

Angermeier PL, Karr JR (1994) Biological integrity versus biological diversity as policy directives. Bioscience 44:690-697

Bates D, Maechler M, Bolker B (2013) lme4: linear mixed effects models using S4 classes. R package version 0.999999-2. http://cran.rproject.org/package $=$ lme 4

Bátori Z, Gallé R, Erdős L, Körmöczi L (2011) Ecological conditions, flora and vegetation of a large doline in the Mecsek Mountains (South Hungary). Acta Bot Croat 70:147-155

Bátori Z, Körmöczi L, Erdős L, Zalatnai M, Csiky J (2012) Importance of karst sinkholes in preserving relict, mountain, and wet-woodland plant species under sub-Mediterranean climate: A case study from southern Hungary. J Cave Karst Stud 74:127-134

Bátori Z, Csiky J, Farkas T, E Vojtkó A, Erdős L, Kovács D, Wirth T, Körmöczi L, Vojtkó A (2014) The conservation value of karst dolines for vascular plants in woodland habitats of Hungary: refugia and climate change. Int J Speleol 43:15-26

Bátori Z, Vojtkó A, Farkas T, Szabó A, Havadtői K, E-Vojtkó A, Tölgyesi C, Cseh V, Erdős L, Maák I, Gunnar K (2017) Large and small-scale environmental factors drive distributions of cooladapted plants in karstic microrefugia. Ann Bot-London 119:301309

Bátori Z, Vojtkó A, Maák IE, Lőrinczi G, Farkas T, Kántor N, Tanács E, Kiss PJ, Juhász O, Módra G, Tölgyesi C, Erdős L, Aguilon DJ, 
Gunnar K (2019) Karst dolines provide diverse microhabitats for different functional groups in multiple phyla. Sci Rep-UK 9:7176

Bátori Z, Vojtkó A, Keppel G, Tölgyesi C, Čarni A, Zorn M, Farkas T, Erdős L, Kiss PJ, Módra G, Breg Valjavec M (2020) Anthropogenic disturbances alter the conservation value of karst dolines. Biodivers Conserv 29:503-525

Borhidi A (1995) Social behaviour types, the naturalness and relative ecological indicator values of the higher plants in the Hungarian flora. Acta Bot Hung 39:9-181

Breg M (2007) Degradation of dolines on Logaško polje (Slovenia). Acta Carsologica 36:223-231

Breg Valjavec M, Zorn M, Carni A (2018a) Bioindication of humaninduced soil degradation in enclosed karst depressions (dolines) using Ellenberg indicator values (Classical Karst, Slovenia). Sci Total Environ 640-641:117-126

Breg Valjavec M, Zorn M, Čarni A (2018b) Human-induced land degradation and biodiversity of karst landscape: on the example of karst depressions (dolines). Land Degrad Dev 29:3823-3835

Chytrý M, Tichý L, Holt J, Botta-Dukát Z (2002) Determination of diagnostic species with statistical fidelity measures. J Veg Sci 13:79-90

De Waele J (2009) Evaluating disturbance on Mediterranean karst areas: the example of Sardinia (Italy). Environ Geol 58:239-255

Dövényi Z (ed) (2010) Magyarország kistájainak katasztere. MTA Földrajztudományi Kutató Intézet, Budapest

Ellenberg H (1950) Landwirtschaftliche Pflanzensoziologie I. Unkrautgemeinschaften als Zeiger für Klima und Boden. Ulmer Verlag, Stuttgart

Erdős L, Bátori Z, Penksza K, Dénes A, Kevey B, Kevey D, Magnes M, Sengl P, Tölgyesi C (2017a) Can naturalness indicator values reveal habitat degradation? A test of four methodological approaches. Pol J Ecol 65:1-13

Erdős L, Tölgyesi C, Bátori Z, Yu A, Semenishchenkov M, Magnes (2017b) The Influence of forest/grassland proportion on the species composition, diversity and natural values of an eastern Austrian forest-steppe. Russ J Ecol 48:350-357

Ford DC, Williams PW (2007) Karst hydrology and geomorphology. Wiley Chichester

Gams I (2000) Doline morphogenetical processes from global and local viewpoints. Acta Carsologica 29:123-138

Goldblum D (1997) The effects of treefall gaps on understorey vegetation in New York State. J Veg Sci 8:125-132

Kemencei Z, Farkas R, Páll-Gergely B, Vilisics F, Nagy A, Hornung E, Sólymos P (2014) Microhabitat associations of land snails in forested dolinas: implications for coarse filter conservation. Community Ecol 15:180-186

Kiss PJ, Tölgyesi C, Bóni I, Erdős L, Vojtkó A, Maák IE, Bátori Z (2020) The effects of intensive logging on the capacity of karst dolines to provide potential microrefugia for cool-adapted plants. Acta Geogr Slov 60:37-48

Kovačič G, Ravbar N (2013) Analysis of human induced changes in a karst landscape - the filling of dolines in the Kras plateau, Slovenia. Sci Total Environ 447:143-151

Li XY, Contreras S, Solé-Benet A (2007) Spatial distribution of rock fragments in dolines: a case study in a semiarid Mediterranean mountain-range (Sierra de G ador, SE Spain). Catena 70:366-374

North LA, van Beynen PE, Parise M (2009) Interregional comparison of karst disturbance: west-central Florida and southeast Italy. J Environ Manage 90:1770-1781

Oksanen J, Blanchet FG, Friendly M, Kindt R, Legendre P, McGlinn D, Minchin PR, O’Hara RB, Simpson GL, Sólymos P, Stevens MHH,
Szoecs E, Wagner H(2019) Vegan: Community ecology. http:// CRAN.R-project.org/package=vegan

Öztürk MZ, Savran A (2020) An oasis in the Central Anatolian steppe: the ecology of a collapse doline. Acta Biologica Turcica 33:100 113

Paillet Y, Bergés L, Hjältén J, Ódor P, Avon C, Bernhardt-Römermann M, Bijlsma RJ, de Bruyn L, Fuhr M, Grandin U, Kanka R, Lundin L, Luque S, Magura T, Matesanz S, Mészáros I, Sebastià MT, Schmidt W, Standovár T, Tóthmérész B, Uotila A, Valladares F, Vellak K, Virtanen R (2010) Biodiversity differences between managed and unmanaged forests: meta-analysis of species richness in Europe. Conserv Biol 24:101-112

Palumbi SR (2001) Humans as the world's greatest evolutionary force. Science 293:1786-1790

Parise M, Pascali V (2003) Surface and subsurface environmental degradation in the karst of Apulia (southern Italy). Environ Geol 44:247256

Pickett STA, White P (1985) The ecology of natural disturbance and patch dynamics. Academic Press, Orlando

Raschmanová N, Miklisová D, Kováč L, Šustr V (2015) Community composition and cold tolerance of soil Collembola in a collapse karst doline with strong microclimate inversion. Biologia 70:802811

R Core Team (2018) R: A language and environment for statistical computing. R Foundation for Statistical Computing, Vienna

Redžić S, Barudanović S, Trakić S, Kulijer D (2011) Vascular plant biodiversity richness and endemo-relictness of the karst mountains Prenj, Čvrsnica and Čabulja in Bosnia and Herzegovina (W. Balkan). Acta Carsologica 40:527-555

Sauro U (2003) Dolines and sinkholes: aspects of evolution and problems of classification. Acta Carsologica 32:41-52

Stockwell CA, Hendry AP, Kinnison MT (2003) Contemporary evolution meets conservation. Trends Ecol Evol 18:94-101

Tichý L (2002) JUICE, software for vegetation classification. J Veg Sci 13:451-453

Tilman D, Lehman C (2001) Human-caused environmental change: impacts on plant diversity and evolution. Proc Natl Acad Sci USA 98: $5433-5440$

Tinya F, Márialigeti S, Király I, Németh B, Ódor P (2009) The effect of light conditions on herbs, bryophytes and seedlings of temperate mixed forests in Örség, Western Hungary. Plant Ecol 204:69-81

Trombulak SC, Omland KS, Robinson JA, Lusk JL, Fleischner TL, Brown G, Domroese M (2004) Principles of conservation biology: recommended guidelines for conservation literacy from the education committee of the Society for Conservation Biology. Conserv Biol 18:1180-1190

Van Beynen P, Brinkmann R, Van Beynen K (2012) A sustainability index for karst environments. J Cave Karst Stud 74:221-234

Vilisics F, Sólymos P, Nagy A, Farkas R, Kemencei Z, Hornung E (2011) Small scale gradient effects on isopods (Crustacea: Oniscidea) in karstic sinkholes. Biologia 66:499-505

White WB, Culver DC, Herman JS, Kane TC, Mylroie JE (1995) Karst Lands. The dissolution of carbonate rock produces unique landscapes and poses significant hydrological and environmental concerns. Am Sci 83:450-459

Whiteman CD, Haiden T, Pospichal B, Eisenbach S, Steinacker R (2004) Minimum temperatures, diurnal temperature ranges, and temperature inversion in limestone sinkholes of different sizes and shapes. J Appl Meteorol 43:1224-1236 